\title{
Changes in local distribution and numbers of staging and winter- ing Bean Geese Anser fabalis in Scania, south Sweden 1977/1978- 2016/2017
}

\author{
Förändringar i lokalutbredning och antal hos rastande och övervintrande sädgäss \\ Anser fabalis $i$ Skåne, södra Sverige 1977/1978-2016/2017
}

\author{
LEIF NILSSON
}

\begin{abstract}
Scania in southern Sweden is an important staging and wintering province for the Bean Goose Anser fabalis, especially for the Taiga form $A . f$. fabalis. Based on counts in October, November and January 1977/1978$2016 / 2017$, and observations of neck-banded individuals, the changes in local distribution are described. When the counts started, large numbers were counted already in October, but autumn numbers steadily decreased as the geese stayed further north in Sweden. The January counts on the other hand increased as the geese wintered in Scania in successively larger numbers rather than leaving Sweden. In January 2017, more than 40000 or two-

thirds of the global population of Taiga Bean Goose were counted in Scania. Within the province, more and more geese concentrated to inland areas and instead of using the Öresund coastal region as in earlier years. Birds from different breeding areas, e.g. from Finland and Sweden, used different parts of Scania. In recent years 3000-9000 of Tundra Bean Geese Anser f. rossicus have been wintering in a small area in northeast Scania.

Leif Nilsson, Department of Biology, Biodiversity, Ecology Building, S-223 62 Lund, Sweden.

Email:leif.nilsson@biol.lu.se
\end{abstract}

Received 16 May 2017, Accepted 20 September 2017, Editor Jonas Waldenström

\section{Introduction}

Most European Goose populations have shown remarkable increases during recent decades (e.g. Fox et al. 2010, Nilsson 2013). This does, however, not apply to the Taiga Bean Goose Anser $f$. fabalis, which recently was red-listed because of an unfavorable conservation status (Marjankangas et al. 2015). Accordingly, an International Single Species Action Plan (ISSAP) was established for the Taiga Bean Goose by AEWA (The African-Eurasian Waterfowl Agreement; Marjankangas et al. 2015), and work to change the situation has been initiated under the newly established European Goose Management Platform (EGMP). However, there was concern about the situation for this subspecies much earlier, and in 1975 the Nordic Collegium for Wildlife Research (NKV) established a Nordic Bean Goose Project (Nilsson \& Fog 1984). This lead to the start of large-scale neck-banding programs in the Nordic countries in addition to regular goose counts in Sweden (Nilsson 2013).

It was early established that Sweden was a key area for the Taiga Bean Goose, especially during migra- tion but also in normal winters (Nilsson 1984, Nilsson et al. 1999, Fox et al. 2010). Within Sweden, the southernmost province, Scania, was of special importance for the Taiga Bean Geese. In the 1950s, during the first major studies of the species in the country (Markgren 1963, Mathiasson 1963), the absolute majority of autumn staging and wintering Bean Geese were found in this province. Over the years, there has been a change in the distribution of especially autumn staging Bean Geese in the country which now changed their autumn staging to sites further north in the country (short stopping). Scania is not so important anymore at this time of the year and the Bean Geese arrive later in Scania in more recent years compared to before (Nilsson 2013). Scania is still the most important winter area for the Bean Geese in the country. Internationally, a large proportion of the entire population of Taiga Bean Geese are found in the province during the winter (Fox et al. 2010, Nilsson 2013, Marjankangas et al. 2015).

In the present contribution, I analyze count data from the national goose counts and local sightings 


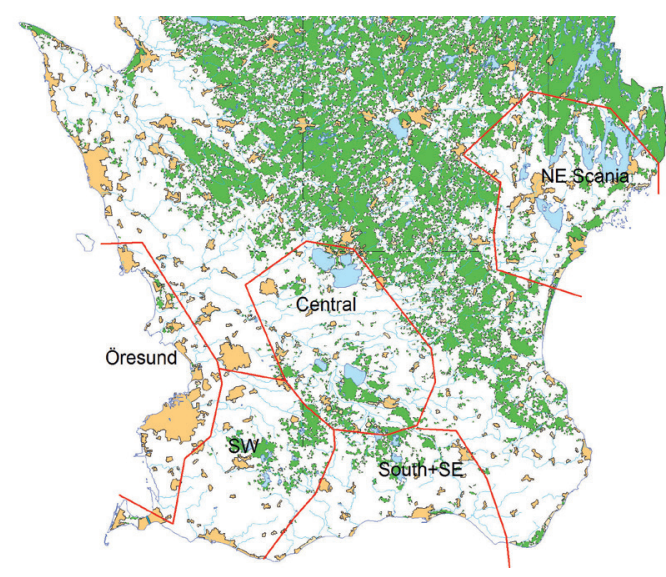

Figure 1. Map of Scania, southernmost Sweden with the division into units used for analyzing the goose counts in the province. The four areas Öresund, SW, Central and South + SE form the larger unit SW Scania.

Karta över Skåne med indelning $i$ större delområden för analys av gåsinventeringarna i provinsen. The fyra delområdena Öresund, SW, Central samt South + SE utgör tillsammans den större enheten SV Skåne.

in Scania from different neck-banding programs to establish the present use of different parts of the province by the Bean Geese and to elucidate changes in the pattern of local distribution and numbers over the last forty years. The knowledge of the local distribution of Bean Geese, especially the differences in local distribution between the two forms of the species is of importance for the adaptive management plan for the Taiga Bean Goose which occur close to the more common Tundra Bean Goose.

\section{Material and methods}

The goose counts in Scania are part of the national and international goose counts coordinated by Wetlands International. Counts in Scania started in 1977/1978 and they have continued ever since. In the present contribution, data is included from counts in October, November and January from the start up to and including $2016 / 2017$, i.e. for 40 years. During the first decade, counts were made every month from October to March/April. Counts from the early years for these months have been analyzed and presented by Nilsson \& Persson (1984). Linear regression was used to test for possible trends in the goose counts.

The main goose areas in Scania lie in the south- west and northeast (Figure 1). The areas shown in the map were covered during the counts by observers that checked every possible field for the occurrence of staging and wintering geese. NE Scania consists of six counting units, but is treated as a unit here as there were no consistent differences in appearance of the Bean Geese between the units during different times of the year. In the same way, SW Scania has 17 units, but for the present analysis they are pooled into four larger groups showing similar seasonal appearance of the geese.

Over the years, the Taiga Bean Geese and Tundra Bean Geese have regularly been separated in SW Scania, where normally very few Tundra Bean Geese have been found (Kampe-Persson 2011). The same also applied to NE Scania during the early years, but in later years, Tundra Bean Geese have started to winter here in numbers. During the last four winters the two forms have been separated also in NE Scania.

Neck banding was an important part of the Nordic Bean Goose Project. During 1976-1980, 156 Bean Geese were caught by cannon nets and neckbanded at Lake Vombsjön in SW Scania (Figure 4, see Nilsson 1984). Neck banding started in Finland in 1978 and during the period 1978-1994, 710 Bean Geese were marked. Catching and neck banding was resumed in 2002, and during 2002-2009 another 173 Bean Geese were neck-banded in Finland. Neck banding of Bean Geese in Finland were mainly undertaken in the breeding (and moulting) areas but also on some spring staging areas in the north. For more information about these marking operations, see Nilsson 1984, Nilsson \& Pirkola 1991 and Nilsson 2011). Finally, Bean Geese were neck banded during spring migration in 2008 and 2009 in staging sites close to Umeå and Luleå in northern Sweden. In all, 45 Taiga Bean Geese and 30 Tundra Bean Geese were neck-banded here during these two springs.

As a part of the Bean Goose project, the staging and wintering areas were actively searched for neck-banded geese. During the monthly counts, all Bean Goose flocks seen on the ground were actively scanned for the occurrence of neck-banded birds. The same applies to the regular goose counts during later years. In addition to the counts, known concentration areas for the species were regularly checked for the occurrence of marked birds during the entire season. In addition, observations were collected from birdwatchers active in the province (for further details see Nilsson 1984, Nilsson \& Pirkola 1991). 


\section{Results}

\section{Goose counts in Scania}

During the first eight years of goose counting, 10 000-25 000 Bean Geese were counted in SW Scania in October (Figure 2). Numbers then decreased markedly and very few Bean Geese were counted in this month in the last two decades. October numbers in NE Scania were low for the entire period. The decrease in October counts for Scania was highly significant (linear regression $r=-0.80$, $\mathrm{P}<0.001$, d.f. $=39$ ). As was shown in the national analysis, the Bean Geese were short stopping and new staging habits established further north in south Sweden (Nilsson 2013).

November totals for Scania were also high during the early years of goose counting but decreased during the years (Figure 2). Still, the overall picture shows a decrease over forty years $(\mathrm{r}=$ $-0.48, \mathrm{P}<0.002$, d.f. $=39$ ). The decrease was concentrated to SW Scania $(\mathrm{r}=-0.75, \mathrm{P}<0.001$, d.f. $=$ 39). Counts in NE Scania did not show any clear long-term trend but fluctuated between years $(\mathrm{r}=$ 0.27 , n.s., d.f. $=39$ ). A larger proportion of all Bean Geese counted in Scania stayed in the NE part of the province in later years.

January totals for Scania showed a marked and significant increase over the four decades from about 10000 to 20000 during the first four years to between 30000 and 40000 during recent years with a peak of more than 45000 in January 2017 (Figure 2). The increase was highly significant $(\mathrm{r}=$ $0.60, \mathrm{P}<0.001$, d.f. $=39$ ). The increase was mostly localized to SW Scania $(\mathrm{r}=0.63, \mathrm{P}<0.001$, d.f. $=$ 39) whereas the increase was not so marked for NE Scania $(\mathrm{R}=0.31, \mathrm{P}=0.05$, d.f. $=39)$.

In the last few years it was found that a proportion of the Bean Geese in NE Scania were Tundra Bean Geese even if the majority were Taiga Bean Geese. During the last four seasons, the observers have separated the two forms of Bean Geese (Table 1) even if it was not possible in all cases. Number of Tundra Bean Geese counted in NE Scania in the four winters varied between 800 and 6631. In SW Scania, the number of Tundra Bean Geese have been small with the exception of 2015 when 4073 individuals were counted.

In NE Scania, there were no clear differences in the distribution of the wintering Bean Geese between the counting units during the whole period of four decades. On the other hand, in SW Scania there were marked changes in the utilization of the different parts of the area over the 40 -year period

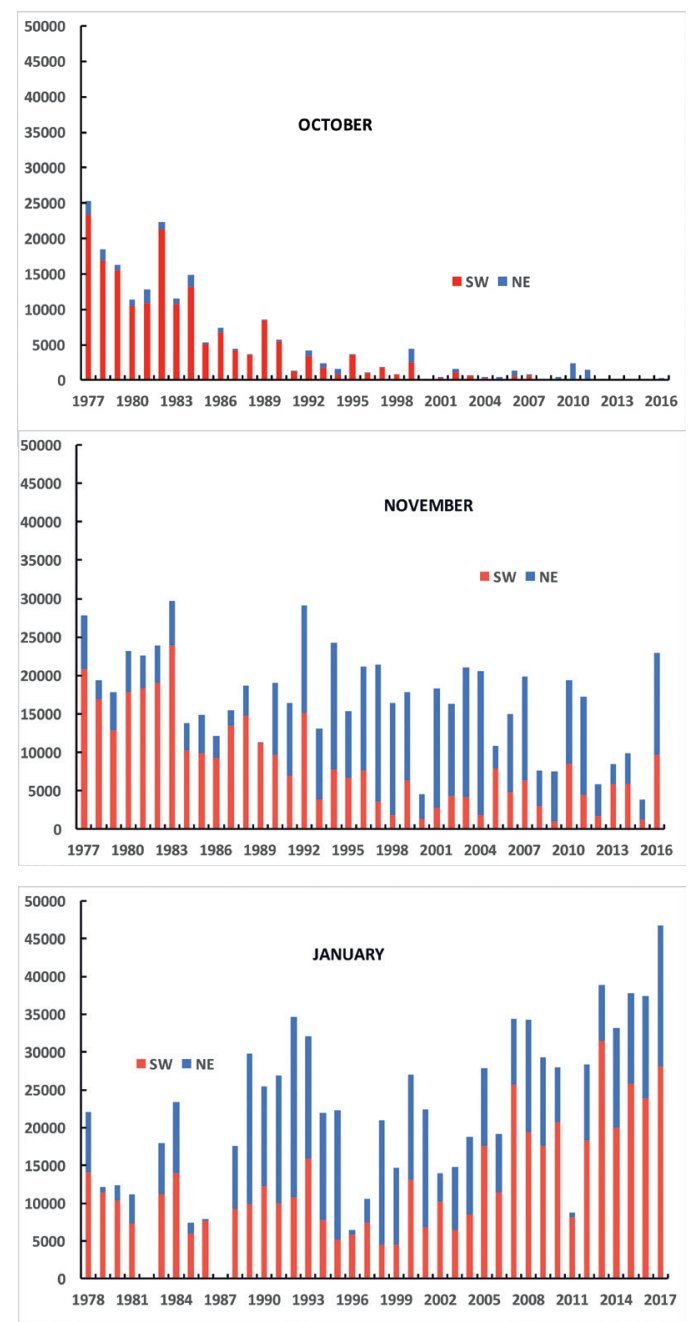

Figure 2. Total number of Bean Geese Anser fabalis counted in SW and NE Scania in October, November and January 1977/78-2016/17.

Totalantalet sädgäss Anser fabalis räknade i SW resp. NE Skåne i oktober, november och januari 1977/78-2016/17.w

both for staging Bean Geese in late autumn and for wintering Bean Geese (Figure 3). During the first half of the study period staging Bean Geese in November used the Öresund region in decreasing numbers. The decrease was parallel to the overall decrease in staging Bean Geese found in the counts for Scania.

In the first ten years, the wintering Bean Geese regularly used the coastal districts. In the cold winter of 1979 , close to 10000 Bean Geese were found 

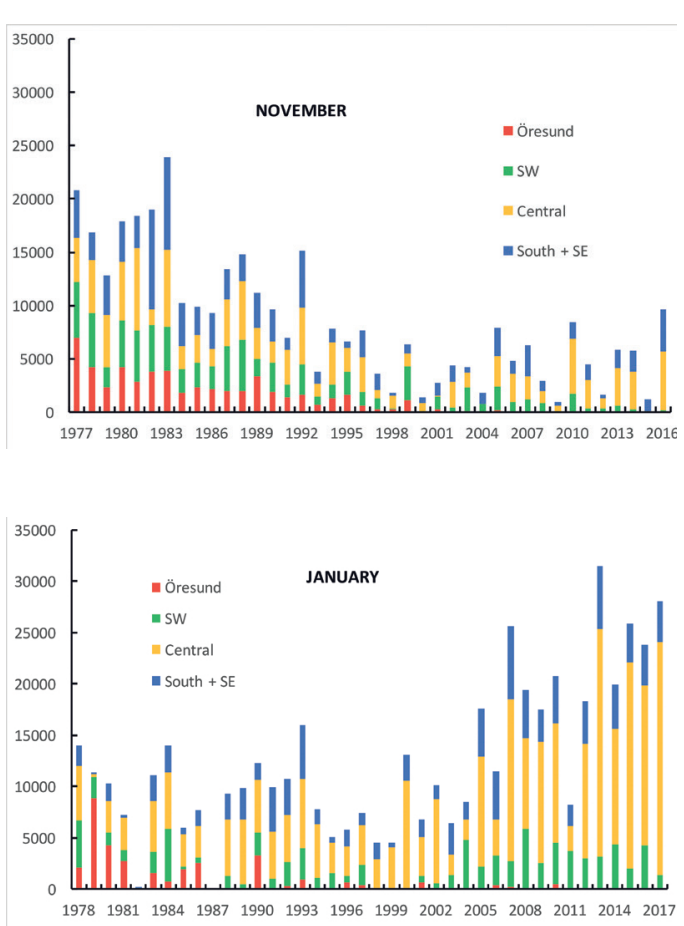

Figure 3. Total number of Bean Geese Anser fabalis in the four subdivisions of SW Scania (see Figure 1) in November and January 1977/78-2016/17.

Antalet sädgäss Anser fabalis i fyra delområden av SV Skåne (se Figur 1) i november och januari 1977/78-2016/17. in the Öresund region in January, related to much snow in inland Scania this cold winter. Few Bean Geese remained in Scania during the following hard winters in 1982 and 1987. The last winter with any larger flocks counted in the Öresund area was 1990. Later hardly any Bean Geese were counted at the Öresund coast in winter. In later years, the central area in the SW of Scania took a more dominating position as a staging and wintering area for Bean Geese.

\section{Local neckband sightings}

The majority of the Bean Geese caught and neckbanded at Lake Vombsjön in SW Scania during 1976-1980 (Figure 4) stayed in the general feeding areas around the lake during autumn and winter. There were some movements from Vombsjön to the coast at Barsebäck in the Öresund during November and December; Barsebäck being an important staging area for Bean Geese during the early years of the study. In January and February, relatively few local sightings were obtained showing a spread over SW Scania. The Bean Geese showed no differences in local distribution between the marking year and later winter seasons.

The Bean Geese marked during the early period (1978-1994) in Finland (Figure 5) were found in good numbers both in NE and SW Scania. In the arrival period in October, relatively few sightings were made in both parts of Scania but in Novem-

Table 1. Number of Bean Geese counted in Scania in January 2014-2017 separated on Taiga Bean Geese Anser fabalis fabalis and Tundra Bean Geese Anser fabalis rossicus.

Antalet sädgäss räknade i Skåne i januari 2014-2017 uppdelade på taigasädgäss Anser fabalis fabalis och tundrasädgäss Anser fabalis rossicus.

\begin{tabular}{lrrrr}
\hline & 2014 & 2015 & 2016 & 2017 \\
\hline NE SCANIA & & & & \\
Taiga Bean Goose & 2610 & 6359 & 7250 & 13340 \\
Tundra Bean Goose & 9116 & 800 & 3515 & 2680 \\
Taiga/Tundra Goose & 1185 & 4316 & 2743 & 4536 \\
Total & 12911 & 11475 & 13508 & 18711 \\
\hline SW SCANIA & & & & \\
Taiga Bean Goose & 19830 & 21960 & 23528 & 24256 \\
Tundra Bean Goose & 80 & 4073 & 90 & 286 \\
Total & 19910 & 26033 & 23618 & 24542 \\
\hline
\end{tabular}



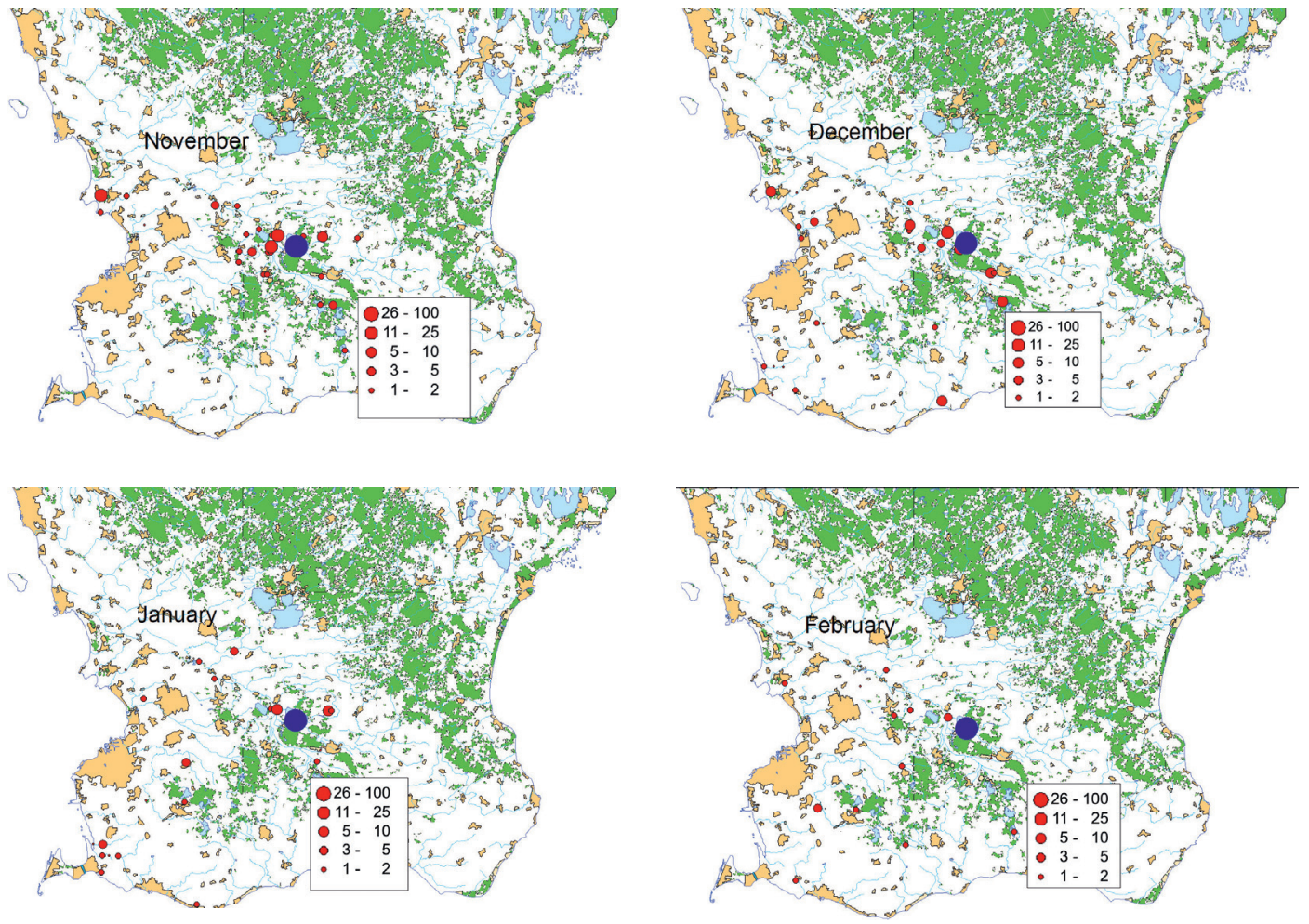

Figure 4. Local distribution of sightings in Scania of Bean Geese Anser fabalis neck-banded at Vombsjön (Blue) in 1977-1980. Lokal fördelning av observationer i Skåne av sädgäss Anser fabalis halsmärkta vid Vombsjön (Blå cirkel) 1977-1980.

ber they were well spread in both the SW and the NE. As was the case for the geese neck-banded at Lake Vombsjön some Finnish marked Bean Geese were seen at Barsebäck in the Öresund area during the early years, but most stayed in the inland areas, especially in the central part of SW Scania. There were also a few sightings from the coast in the SW.

Comparing the distribution of sightings of neckbanded Bean Geese from the second marking period in Finland (2002-2009) with the first period (1978-1994), some differences were found (Figure $5,6)$. During the latter period fewer Bean Geese arrived to Scania during the early part of the autumn, with only small numbers of re-sightings from October and November. The Bean Geese from the later period were clearly more concentrated to NE with relatively few sightings from the SW during October-December. In January, marked Bean Geese were seen in numbers spread over both parts of Scania. In February, the geese in both parts of Scania were more concentrated than in January. By March most Bean Geese had left Scania, fewer remained in SW Scania then in NE.
The majority ( $81 \%$ of 53 individuals) of the Taiga Bean Geese marked on spring migration in northern Sweden, staging and wintering in Scania, were concentrated to SW Scania while only $9 \%$ were found in NE Scania (Figure 7). Tundra Bean Geese marked in spring in northern Sweden were mostly sighted in NE Scania ( $81 \%$ of 32 individuals; Figure 7, also cf. De Jong et al. 2013). The remaining individuals of both forms were reported from sites north of Scania.

In contrast to the concentration of the sightings of Taiga Geese from northern Sweden to SW Scania ( $81 \%$ of 53 sightings), the Taiga Bean Geese from northern Finland in the later period were more spread over the two parts of Scania. 44\% (of 243 ) sightings were from SW Scania, whereas $56 \%$ were from NE.

\section{Discussion}

With a wintering population of probably at least 40000 Taiga Bean Geese in Scania in January 2017 , the area is clearly the globally most import- 

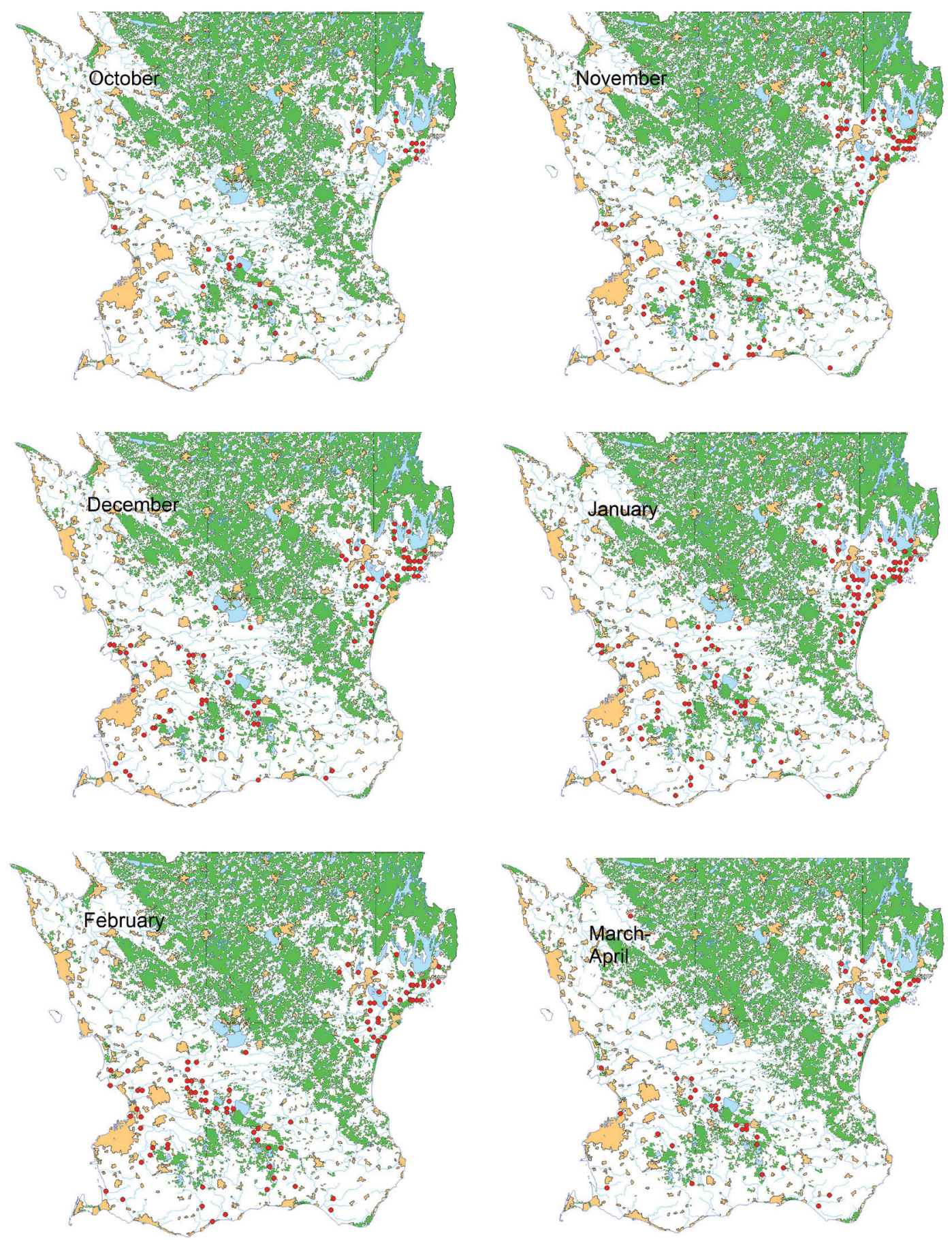

Figure 5. Local distribution of sightings in Scania of Bean Geese Anser fabalis neck-banded in Finland in 1978-1994.

Lokal fördelning av observationer i Skåne av sädgäss Anser fabalis halsmärkta i Finland 1978-1994. 

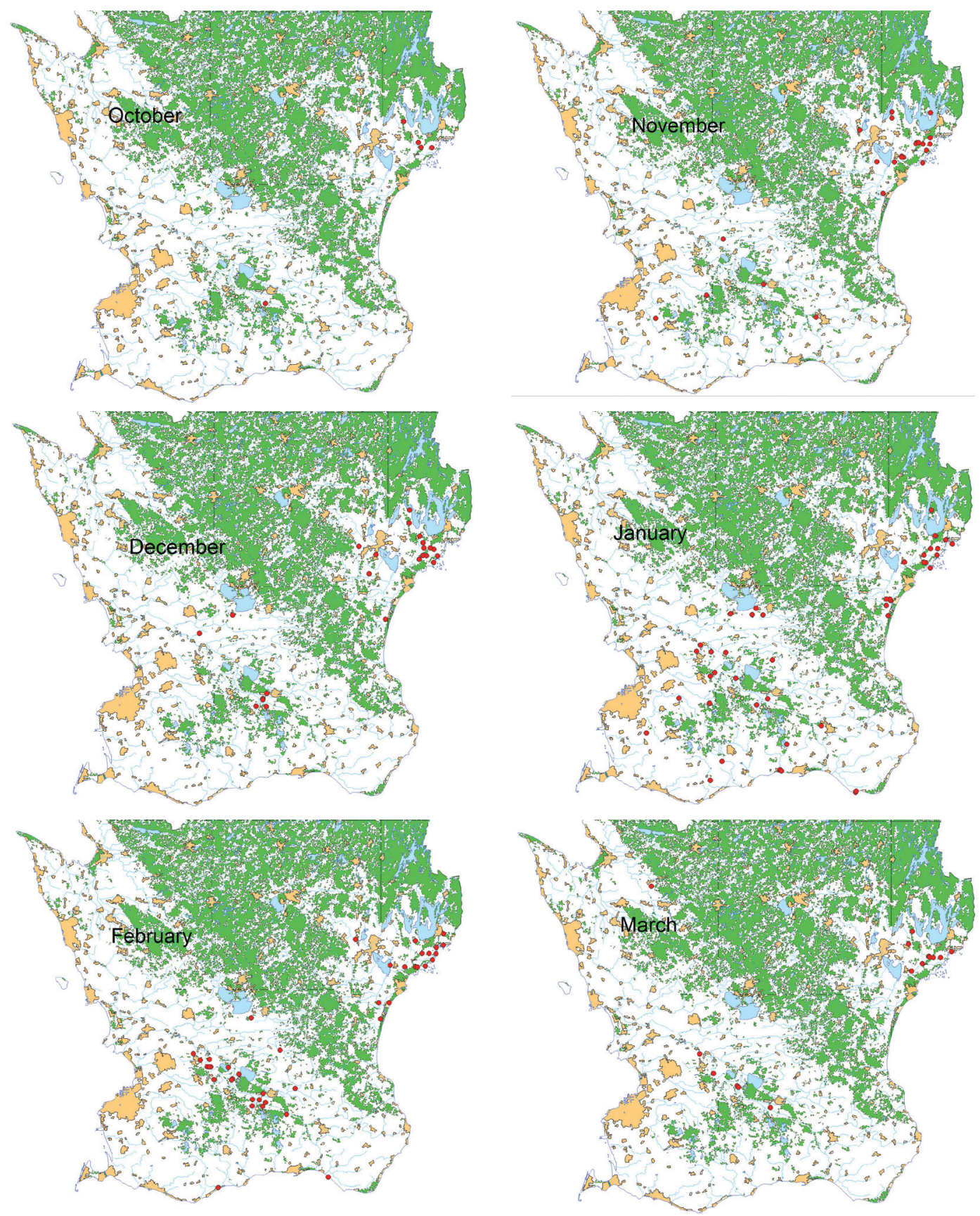

Figure 6. Local distribution of sightings in Scania of Bean Geese Anser fabalis neck-banded in Finland in 2002-2009.

Lokal fördelning av observationer $i$ Skåne av sädgäss Anser fabalis halsmärkta i Finland 2002-2009. 

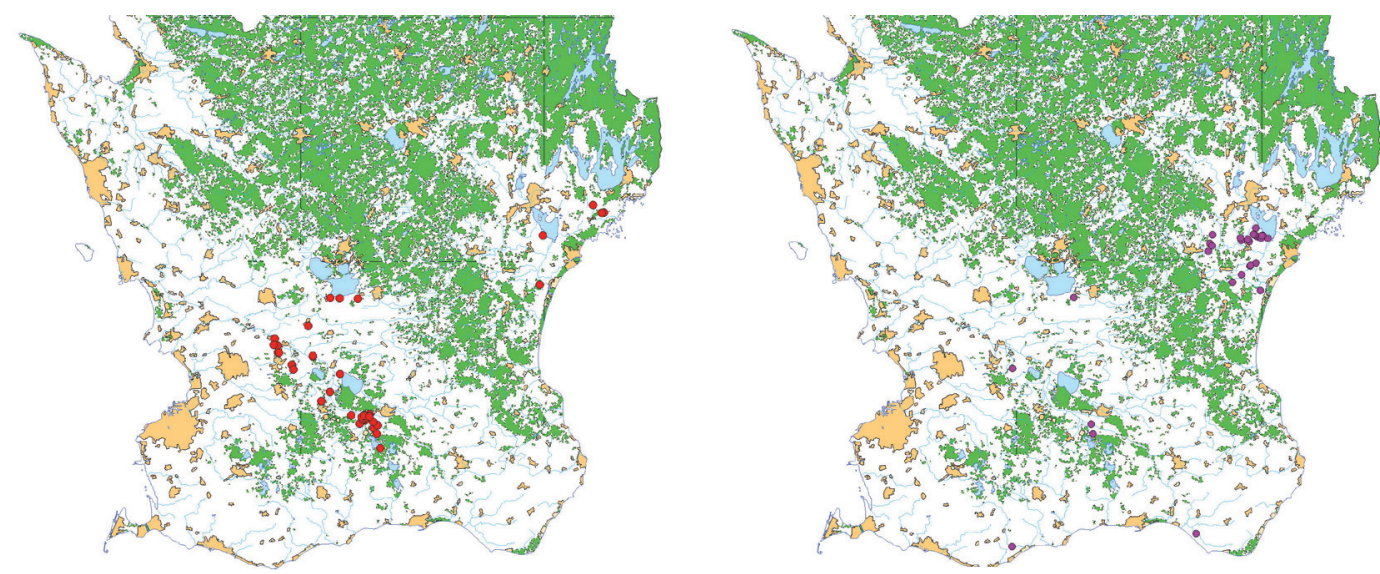

Figure 7. Local distribution of sightings in Scania of Bean Geese Anser fabalis neck-banded during spring migration in northern Sweden (Umeå and Luleå) in 2008 and 2009. Left map Taiga Bean Goose Anser f. fabalis and Right map Tundra Bean Goose Anser f. rossicus.

Lokal fördelning av observationer i Skåne av sädgäss Anser fabalis halsmärkta i norra Sverige (Umeå och Luleå) 2008 och 2009. Vänstra kartan visar Taigasädgås Anser f. fabalis och högra kartan tundrasädgås Anser f. rossicus.

ant winter area for the subspecies. This is about $65 \%$ or more of the total winter population of the subspecies. However, the estimates of the total population of Taiga Bean Geese varies between different reports. In the action plan for the Taiga Bean Goose (Marjankangas et al. 2015) the counts reported from the winter of 2014/2015 yielded a total of c 52600 Taiga Bean Geese. This is lower than the estimate of 63000 presented by Fox et al. (2010). The 2016 counts from Sweden indicates an autumn population in the country of at least 60000 (Hakon Kampe-Persson, pers. comm.), implying an even higher total population for the Taiga Bean Goose globally.

The proportion of the total population of Taiga Bean Geese staying in Scania for the winter has increased during the last forty years, the local January trend presented here being significantly increasing at the same time as the total population has decreased. In the early neck-banding studies, some Bean Geese migrated to the southwest being seen in Denmark, Germany and the Netherlands (Nilsson 1984, Nilsson \& Pirkola 1991), and in cold winters hardly any Taiga Bean Geese remained in Sweden (Nilsson 2013). On the other hand, no geese from the later Finnish study period migrated to western Germany or the Netherlands (Nilsson 2011).

When the studies started, Scania was also an important autumn staging area for the Taiga Bean Geese but especially in October, and also November, counts decreased markedly, and in the latter part of the study period, very few Bean Geese reached Scania in October. As has been documented in Nilsson \& Persson (1984) and in Nilsson (2013), the Bean Geese stopped for staging further north in south Sweden and a number of new major staging areas were established there, some of which had been used for spring staging earlier.

This short stopping seen over the entire range of Taiga Bean Geese is certainly an effect of the milder autumns and winters that make it possible for the geese to stay further north than in earlier years. The same phenomenon was also reported for other goose species such as the Greylag Goose Anser anser (Nilsson 2006, 2013, Ramo et. al. 2015).

Nilsson \& Persson (1991b) analyzed the local distribution of Bean Geese in Scania during the early years of the Nordic Bean Goose project. About half (40 out of 79) of the individuals re-sighted during the same season stayed in the Vomb-area where they were marked but the rest spread over the province. Several of the Bean Geese marked at Vomb were later in the season found at the coast, but this exchange with the coast was not found in the geese marked later (Finnish breeding birds); this pattern is also apparent from the count data.

When comparing the local distribution of the birds marked at Lake Vombsjön in the early years with Finnish marked Bean Geese from the first study period, the distribution in SW Scania was similar between the two data sets. The re-sightings from both groups were concentrated to the central areas around Vomb but the Finnish-marked birds were 
more dispersed over other parts of SW Scania. Moreover, an important proportion of them were also seen in NE Scania.

Both the count data and the re-sighting data clearly show a concentration of the Bean Goose to the inland parts of Scania in the latter part of the study. This applies both to the decreasing numbers arriving into Scania already in November and to the increasing wintering population in the province. The reasons for this change in local distribution are not clear. There have been no marked changes in the availability of different crops suitable for feeding Bean Geese between the coastal areas and the other parts of SW Scania during the study period (Nilsson \& Persson 1991a, Nilsson \& Kampe-Persson 2013).

During the study period, there has also been marked changes in staging and wintering numbers of other goose populations in Scania (Nilsson 2013). The local breeding population of Greylag Geese in Scania was very small in the late 1970s but have increased exponentially over the years. In the early years of the study, the Greylag Geese left Scania quite early in the autumn, but habits changed, and in recent years large numbers of Greylag Geese winter in south Sweden. In the same way, large numbers of Barnacle Geese Branta leucopsis also started to use Scania as an important autumn staging area in recent years. However, there is no clear indication of competition between the goose species, the Bean Geese had stopped using the coastal areas several years before the changes in occurrence was noted in the Greylag Goose and Barnacle Goose.

In the material presented here, Bean Geese from different breeding regions show differences in their appearance in the winter quarters. Taiga Bean Geese marked in the breeding areas of northern Finland were more spread over the goose areas in Scania, whereas Taiga Bean Geese marked on spring staging at the coast of the Bothnian Bay were mostly seen in the SW part of Scania. In this context, it is also interesting to note that the Tundra Bean Geese marked on the same spring staging areas as the Taiga Bean Geese in northern Sweden were concentrated to a relatively small area in NE Scania. These differences in local distribution in the winter areas can be of importance for the management of goose populations.

\section{Acknowledgements}

Financial support for the Nordic Bean Goose Project was obtained from the Nordic Collegium for Wildlife Research. Neck-banding in northern Sweden were obtained from the Swedish Transport Administration and Carl Tryggers Stiftelse för Vetenskaplig Forskning. The goose counts in Sweden were supported by grants from the Swedish Hunters Association. I also wish to thank field workers that have taken part in the catching operations in different areas, goose counters and observers that have checked goose flocks for neckbands.

\section{References}

De Jong, A., Heinicke, T., Aarvak, T. \& Öien, I.J. 2013. Movements of Tundra Bean Goose Anser fabalis rossicus neck-banded in northern Scandinavia. Ornis Norvegica 36: $28-31$.

Fox, A. D. , Ebbinge, B.S., Mitchell, C., Heinicke, T., Aaarvak, T., Colhoun, K., Clausen, O., Dereliev, S., Farago, S., Koffijberg, K., Kruckenberg, H., Loonen, M.J.J., Madsen, J., Mooij, J., Musil, P., Nilsson, L., Pihl, S. \& van der Jeugd, H. 2010. Current estimates of goose population sizes in Western Europe, a gap analysis and an assessment of trends. Ornis Svecica 20: 115-127.

Kampe-Persson, H. 2011. How large proportion of the Bean Geese counted in Sweden was made up of Taiga Bean Geese Anser fabalis fabalis? Ornis Svecica 21: 58-60. Swedish with English summary.

Marjakangas, A., Alhainen, M., Fox, A.D., Heinicke, T., Madsen, J. Nilsson, L. \& Rozenfeld, S. 2015 International Single Species Action Plan for the Conservation of the Taiga Bean Goose (Anser fabalis fabalis). AEWA Technical Series No. 56. Bonn, Germany.

Markgren, G. 1963. Migrating and wintering geese in southern Sweden. Ecology and Behaviour Studies. Acta Vertebratica 2: 297-418.

Mathiasson, S. 1963. The Bean Goose, Anser fabalis (Latham), in Skåne. Sweden with remarks on occurrence and migration trough northern Europe. Acta Vertebratica 2: 419-533.

Nilsson, L. 1984. Migrations of Fennoscandian Bean Geese, Anser fabalis. Swedish Wildlife Research 13: 83-106.

Nilsson, L. 2006. Changes in migration patterns and wintering areas of south Swedish Greylag Geese Anser anser. Waterbirds around the World. Eds. G.C .Boere., C.A. Galbraith \& D.A. Stroud. The Stationary Office. Edinburgh, UK. Pp. 514-516.

Nilsson, L. 2011. The migrations of Finnish Bean Geese $A n$ ser fabalis in 1978 - 2011. Ornis Svecica 21: 157-166.

Nilsson, L. 2013. Censuses of autumn staging and wintering goose populations in Sweden 1977/78 - 2011/12. Ornis Svecica 23: 3-45.

Nilsson, L. \& Fog, M. 1984. (eds.). Studies on Fennoscandian populations of Bean Goose (Anser fabalis), Greylag 
Goose (Anser anser) and White-fronted Goose (Anser erythropus). Swedish Wildlife Research 13:1-221

Nilsson, L., van den Bergh, L. \& Madsen, J. 1999. Taiga Bean Goose Anser fabalis fabalis. In Madsen, J., Cracknell, G. \& Fox, A.D. (eds.) Goose populations of the Western Palearctic. A review of status and distribution: $p$. 20-36. Wetlands International, Wageningen.

Nilsson, L. \& Kampe-Persson, H. 2013. Field choice of autumn staging and wintering geese in southwestern Sweden 1977/78 - 2011/12. Ornis Svecica 23: 46-60.

Nilsson, L. \& Persson, H. 1984. Non-breeding distribution, numbers and ecology of Bean Goose, Anser fabalis, in Sweden. Swedish Wildlife Research 13: 107-170.

Nilsson, L. \& Persson, H. 1991a. Selection and exploitation of feeding areas by staging and wintering geese in southernmost Sweden. Ornis Svecica 1: 81-92.

Nilsson, L. \& Persson, H. 1991b. Site tenacity and turnover rate of staging and wintering Bean Geese Anser fabalis in southern Sweden. Wildfowl 42: 53-59.

Nilsson, L. \& Pirkola, M.K. 1986. The migration pattern of Bean Geese Anser fabalis in the Baltic area. Vår Fågelvärld Suppl. 11: 147-153.

Nilsson, L. \& Pirkola, M.K. 1991. Migration pattern of Finnish Bean Geese Anser fabalis. Ornis Svecica 1: 69-80.

Ramo, C,. Amat, J.A., Nilsson, L., Schricke, V., RodriguezAlonso, M., Gomez-Crespo, E., Jubete, F., Navedo, J.S., Masero, J.A., Palacios, J., Boos, M., Green, A.J. 2015. Latitudinal-Related Variation in Wintering Population Trends of Greylag Geese (Anser Anser) along the Atlantic Flyway: A Response to Climate Change? Plos one 10(10): e0140181

\section{Sammanfattning}

De flesta europeiska gåsbestånden har visat en markant ökning under senare år (Fox et al. 2010, Nilsson 2013). Detta gäller dock inte taigasädgåsen Anser fabalis fabalis, som blivit rödlistad. Som en följd av detta har man inom AEWA (African Eurasian Waterfowl Agreement) tagit fram en aktionsplan för att försöka återställa en mer positiv situation för denna gåsform. Redan tidigt har dock sädgåsen väckt bekymmer och 1975 startade Nordisk Kollegium för Viltforskning (NKV) ett sädgåsprojekt (Nilsson \& Fog 1984). Detta ledde till omfattande halsringmärkning av sädgäss och till starten av regelbundna gåsinventeringar i Sverige. Redan tidigt fastställdes att Sverige utgör ett nyckelområde för Taigasädgåsen samt att Skåne under stora delar av året är ett speciellt viktigt område för denna gåsform.

I föreliggande uppsats analyseras data från de nationella gåsinventeringarna samt från olika halsmärkningsprojekt för att belysa sädgåsens utnyttjande av Skåne samt förändringar i antal och lokal utbredning under de senaste fyrtio åren.

\section{Material och metoder}

Gåsinventeringarna utgör en del av de nationella och internationella gåsinventeringarna, vilka samordnas av Wetlands International. Inventeringarna startade 1977/78 och pågår fortfarande. I denna studie analyseras inventeringar till och med 2016/17, dvs. de senaste 40 åren. Inventeringarna omfattar månaderna oktober, november och januari.

De viktigaste gåsområdena i Skåne ligger i sydväst resp. nordost (Figur 1). NO Skåne delas i 6 delområden, medan SV (och S) Skåne delas i 17 områden. För de aktuella analyserna utgör NO Skåne en enhet, medan SV Skåne i vissa fall delas i fyra mindre enheter. I SV Skåne har de båda formerna av sädgås (taiga och tundra) regelbundet separerats, men tundragässen har normalt varit få. Under senare år påträffades större antal tundragäss i NE och de fyra senaste vintrarna har man försökt skilja underarterna vid inventeringarna.

Halsmärkning av gäss var en viktig del i det nordiska sädgåsprojektet och 156 gäss fångades och märktes i Vombområdet 1976-1980, medan 710 gäss märktes i Finland under 1978-1994, varefter ytterligare 173 gäss halsmärktes i Finland 2002-2009. I samband med undersökningar kring Botniabanan i Umeå halsmärktes 45 Taigasädgäss och 30 Tundrasädgäss vårarna 2008-2009. Intensiva observationer för att kontrollera förekomsten av märkta gäss genomfördes i bl.a. Skåne under den aktuella perioden.

\section{Gåsinventeringar i Skåne}

När inventeringarna startade inräknades mellan 10000 och 25000 sädgäss i SV Skåne i oktober (Figur 2). Antalet sädgäss i oktober minskade signifikant och under de senaste åren observerades mycket få sädgäss i landskapet i oktober. Gässen stannade längre norrut i Sverige (Nilsson 2013). Novemberinventeringarna visade samma bild, mest för SV Skåne, medan räkningarna inte visade någon klar tendens för den NE delen av landskapet.

Inventeringarna $\mathrm{i}$ januari visade å andra sidan en markant ökande trend från ca 10 000-20 000 under de första åren till mellan 30000 och 40000 de senaste åren (Figur 2). Ökningen var signifikant för både SV och NE Skåne, men mest markant i SV. I de två kallaste vintrarna under perioden (1982 och 1987) sågs knappt några sädgäss i landskapet. Antalen var låga också under andra kalla vintrar, speciellt saknades sädgäss då i den nordöstra delen av landskapet. 
Under de senaste åren konstaterades att ett större antal tundrasädgäss övervintrade i Skåne. Dessa har alltid (med ett undantag) varit sparsamma i sydväst, men i nordöstra Skåne har de separerats först under vintrarna 2014-2017 (Tabell 1).

I SV Skåne konstaterades skillnader i gässens antalsutveckling inom de olika delområdena (Figur 1 och Figur 3). I början av studierna var sädgäss regelbundet förekommande i Öresundsområdet under vintern, men under senare år var de mer och mer koncentrerade till de inre delarna av området.

\section{Observationer av halsmärkta gäss}

Merparten av de sädgäss som märktes vid Vombsjön under höstarna 1977-1980 stannade på födosöksområdena nära Vomb (Figur 4). Under hösten och förvintern noterades en del rörelser till kusten av Öresund främst vid Barsebäck som under dessa år var ett viktigt område för arten.

De sädgäss som märktes i Finland under 19781994 observerades i betydande antal både i SV och NE Skåne (Figur 5) och var väl spridda över resp. område. Liksom Vombgässen observerades rörelser till Öresundskusten under de första undersökningsåren. Senare (2002 - 2009) märkta sädgäss från Finland (Figur 6) visade en klart annan utbredning än de märkta gässen från den tidiga perioden. De anlände dessutom betydligt senare till Skåne.

När det gäller sädgässen märkta på vårlokaler i norra Sverige, så visade taigagässen en markant koncentration till sydvästra Skåne, medan tundrasädgässen var koncentrerade till nordöstra Skåne (Figur 7). En jämförelse mellan taigagässen från de svenska rastlokalerna visade en annan bild än sädgässen från den senare märkperioden i norra Finland. Till skillnad från de svenska gässen var de finska mer jämnt fördelade över både sydvästra och nordöstra Skåne.

\section{Diskussion}

Med åtminstone 40000 Taigasädgäss i Skåne vid januariinventeringen 2017 utgör området det klart viktigaste vinterområdet för denna gåsform med ungefär $65 \%$ eller mer av det totala beståndet för underarten. Till en del kan denna ökning förklaras av att färre sädgäss flyttar vidare mot sydväst jämfört med tidigare år. Denna förskjutning norrut av utbredningen kan också ses i fördelningen av sädgässen i landet vid höstinventeringarna där de i högre grad rastar längre norrut $i$ landet än tidigare (Nilsson 2013). En liknande tendens till "shortstopping" har konstaterats hos andra gåsarter, t.ex. grågåsen (Nilsson 2006, 2013, Ramo et al. 2015).

Märkningar av sädgäss har företagits under olika perioder. Som påvisats här förekommer en hel del skillnader i den lokala utbredningen mellan de olika grupperna av märkta gäss. En tydlig tendens är att sädgässen knappast förekommer i områdena vid Öresund längre. Dessa områden torde tidigare utnyttjats mer då de till skillnad från inlandet har haft mindre snö och därmed gett sädgässen lättare födosöksmöjligheter. Man skulle kanske kunna tänka sig en konkurrenssituation eftersom flera andra gäss ökat under perioden och börjat övervintra i landet. Emellertid övergav sädgässen kustområdena redan innan dessa började utnyttjas av större antal av de andra gåsarterna. 